\title{
Family Constitution and Business Performance: Moderating Factors
}

\section{Rocío Arteaga and Susana Menéndez-Requejo ${ }^{1}$}

\author{
Family Business Review, 2017, vol. 30(4), pag. 320-338 \\ DOI $10.1177 / 0894486517732438$ \\ http://journals.sagepub.com/home/fbr
}

\begin{abstract}
This study analyzes the relationship between implementing a Family Constitution (Protocol) and future family business performance. We analyze a unique sample of 530 Spanish family businesses. Half of these firms received financial aid from the government to implement a Family Protocol during 2003-2013. The analysis reveals that family businesses that implemented a Family Constitution had significantly improved performance within two years after the implementation. The positive relationship between the implementation of a Family Constitution and future firm performance is stronger for firms that had a non-family CEO, had multiple family owners or were controlled by later generations.
\end{abstract}

Keywords: Family Constitution; Family Protocol; performance; family firm heterogeneity; agency theory

\section{Introduction}

A Family Protocol (this term was coined by Gallo \& Ward, 1991 and is also referred to as a "Family Constitution", a "Family Creed" or "Family Agreement") is the result of a process of communication and agreements among owners of a family business that are collated in a written document that includes a set of rules and procedures for governing family business relationships and is signed and ratified by each family member (Carlock \& Ward, 2001; Gallo \& Tomaselli, 2006; Montemerlo \& Ward, 2005; Tapies \& Ceja, 2011). As detailed in the following text, family business consultants agree that, at least in Spain, Family Constitutions address the firm history, the future vision of the family firm, include norms and rules for family members regarding their incorporation into the business, succession planning, shareholder agreements (transfer of shares, dividends, firm valuation), and develop power

${ }^{1}$ University of Oviedo, Spain

\section{Corresponding Author:}

Susana Menéndez-Requejo, University of Oviedo, Avda. Del Cristo s/n, Oviedo, 33071, Spain.

E-mail: srequejo@uniovi.es 
structures in the firm and the family in regard to the company (Board of Directors, Family Council).

Although a Family Constitution is a relevant instrument that is used in practice for facilitating the continuity of family businesses, few academic studies have focused on this topic (Gallo \& Tomaselli, 2006). No formal studies have been conducted to aggregate governance provisions from a large sample of Family Constitutions or determine the impact of family agreements on governance or family firm performance (Gersick \& Feliu, 2014, p.212; Zellweger \& Kammerlander, 2015). To address this research gap, the aim of this study is to analyze the relationship between implementing a Family Constitution and future performance of family businesses.

Because prior studies have not analyzed the effect of Family Protocols on firm performance, a complete and realistic theoretical grounding has not yet been established. This lack of theoretical background motivates our interest in developing a mixed method approach (Kidder \& Fine, 1987) that begins with exploratory interviews to guide theoretical proposals, which will ultimately be tested by conducting a quantitative analysis. We perform in-depth interviews with expert consultants to explore and support theoretical proposals, that are primarily linked to the ability of Family Constitutions to reduce conflict. In addition, we consider alternative explanations and validate popular assumptions regarding the general features and expected effects of Family Constitutions in practice.

Based on agency theory, we posit possible explanations for the proposed positive relationship between Family Constitutions and future firm performance that include the following: an improvement in monitoring managers and firm professionalization that Family Constitutions facilitate (mitigates principal-agent conflicts); an improved alignment between firm owners that shareholder agreements entail (mitigates principal-principal conflicts); and the communication and transparency between family members that Family Constitutions foster (mitigates principal-"super-principal” conflicts). In addition, we explore nuances in the utility of Family Constitutions depending on the relevance of agency conflicts for each firm and expect that this utility will be enhanced by non-family management, multiple family owners, and later-generation control of the firm. We argue that Family Constitution agreements reduce interferences between family, ownership and management and reinforce the positive aspects of socioemotional wealth (SEW) without harming financial performance.

We test our hypotheses on a sample of 530 Spanish family businesses during 2003-2013, including 265 family businesses that received financial aid to implement a Family 
Constitution and a corresponding control group of family businesses that did not implement Family Protocols during this time period.

This study contributes to the extant literature regarding family businesses. First, we contribute to the literature regarding the agency theory and corporate governance of family firms by considering understudied agency costs that are caused by family blockholder conflicts and conflicts that arise from the relationships among family owners and other members of the family. This study responds to a call for research regarding appropriated family governance mechanisms (Nordqvist, Sharma, \& Chirico, 2014; Villalonga, Amit, Trujillo, \& Guzman, 2015; Zellweger \& Kammerlander, 2015). Second, we add to extant literature regarding family firm heterogeneity (Cruz \& Nordqvist, 2012; Eddleston, Kellermanns, Floyd, Crittenden, \& Crittenden, 2013; Ling \& Kellermanns, 2010) by analyzing the moderating role of family involvement in management, ownership structure and the generation that controls the firm. Third, this study offers an empirical basis for and elaborates on a currently unexplored research question (Gersick \& Feliu, 2014) regarding whether a Family Constitution adds value to family firms. In addition, we extend literature regarding family firms (Chrisman, Chua, \& Sharma, 2005; O’Boyle, Pollack, \& Rutherford, 2012) by showing that the implementation of a Family Constitution moderates the relationship between family involvement and firm performance. Finally, we contribute to current literature by exploring privately held family firms, which Mazzi (2011) recognized needed additional analysis. In addition to these contributions to extant literature, the results of this study have implications for practitioners by highlighting the usefulness of Family Constitutions.

The remainder of this paper is structured as follows. The next section presents the exploratory approach used to analyze Family Constitution characteristics. Next, we develop a theoretical framework and propose research hypotheses. Subsequent sections describe the database, the methodology used for the quantitative study and the results of the statistical analyses. Discussion and conclusions are provided in the final section.

\section{Exploratory interviews}

We have been unable to locate any prior studies that analyze the influence of Family Constitutions on firm performance. In general, the topic of Family Protocols has attracted little attention in the literature regarding family businesses (Gallo \& Tomaselli, 2006), despite its relevance for family business in practice. We assume that this research gap may be due to 
the difficulty in obtaining pertinent information at both the aggregate and company levels. It is our goal to contribute to extant literature on this topic.

To define a realistic and comprehensive theoretical framework and considering that the topic of Family Constitutions is a novel focus for research, we previously conduct exploratory interviews. We performed in-depth interviews with consultants who specialize in Family Constitutions in Spain. Spain is characterized by an above-average implementation of Family Protocols and the prominent development of institutions that are linked to family businesses. The Family Business Institute of Spain (www.iefamiliar.com) is an important international leader regarding initiatives such as the Network of Family Business Chairs that exists throughout the Spanish university system and the Family Business Regional Associations that are present and active in every region in Spain. As a result of the work that has been performed by these institutions, public authorities in Spain have occasionally provided support to family businesses to promote continuity and more specifically, to facilitate the implementation of Family Constitutions. We interviewed six consultants who are experts regarding Family Protocols, one consultant for each region (Asturias, Castilla and León, Castilla-La Mancha, La Rioja, The Basque Country and Valencia) ${ }^{2}$ that has provided public funding to support Family Constitutions and we located recipient firms. Rather than using a firm survey, we used in-depth interviews to obtain a broader understanding regarding the characteristics of Family Constitutions and to better grasp the different perceptions of individual family members in each firm (active vs. passive shareholders, family managers, extended family, various generations and ages, family branches).

We noted a great similarity in the consultants' experience and perspectives. The consultants agree that the main objectives of the Protocol are to avoid conflicts in the family business and ensure family control of the firm. Rules and agreements are defined to avoid conflicts that may occur due to overlaps between family, ownership and/or management interests (the classic three-circle model of Tagiuri \& Davis, 1996). In addition, the consultants agree on the primary components of a Family Constitution, which are as follows:

\footnotetext{
${ }^{2}$ We greatly appreciate the valuable, interesting and generous collaboration of the following family business consultant experts: Mr. Pablo Alvarez de Linera (GTA Villamagna, Asturias), Mr. José Fernando de la Fuente (JFF Abogados, Castilla-León), Mr. Diego Garrido (O-Kyaku Europe Consulting, La Rioja), Mrs. Elena López Saralegui (Avanza Asesoría, País Vasco), Mr. Juan Ignacio de Mesa (Abaco Auditores, Castilla-La Mancha), and Mr. Alejandro Ríos (Broseta Abogados, Valencia). These consultants also work in Madrid, other regions, and in other countries. Thank you for your availability and kindness.

We established our first contact with the consultants through the Directors of Family Business University Chairs and the Directors of Family Business Associations in each region. We greatly appreciate their kind and effective mediation.
} 
A) A preamble includes the history, principles, values and vision of the family firm. This section reflects on and clarifies the company's strategy, growth and financing policies.

B) Agreements regarding family in management address management succession and terms for incorporating family members in the firm (training, professional experience, and formal positions) to avoid nepotism. These are key issues when the firm considers incorporating new generations (training activities often occur). The Protocol fosters a family reflection on the need to enhance the firm's professionalization. Although the top manager is generally a family member, the Family Constitution enhances the professionalization of the company by improving its organization and reducing litigation.

C) Agreements regarding ownership regulate share transfers, reinforced majority voting, and succession of ownership. Shareholders of a family-owned business, including minority owners, often have emotional ties to the firm. The consultants agree that a Family Protocol protects the position of minority shareholders (drag-along and tag-along rights, dividend policy, buyout agreements). In addition to the advantages of specifying the economic rights of minority shareholders, a Protocol ensures that new rules apply equally to all owners, such as the hiring of relatives. Furthermore, in the infrequent case of nonfamily minority shareholders, they are generally incorporated into the Protocol process and agreements (or are offered the opportunity to sell their share). The agreement protects the interests of non-family minority shareholders in addition to the interests of the firm, by agreeing to share repurchases when obtained through labor bonds and preventing minority shareholders from hindering the company's progress. Generally, blockholder conflicts are reduced.

D) Agreements regarding governance shape the Family Council and limit the interference of family members in the operation of the business. In regard to the Board of Directors, generally independent members are included. Moreover, it is also an opportunity to take advantage of the participation of qualified minority shareholders. Although clauses relating to arbitration procedures are often included, to elucidate future conflicts between family members, generally, these clauses are broad and not highly detailed.

Consultants report that Family Constitutions contribute to improving the coexistence and cohesion of family generations that are linked to the firm. Protocols improve and channel communication, information (also prior to decision-making) and transparency among family members who are in some manner linked to the firm and guide future generations. A Family Constitution is even more important when families are complex (size and interrelationships) 
regardless of company characteristics. In addition, consultants also noted that most Family Protocols are developed by second generation family firms.

Most Family Constitutions include a minimum of 20-25 pages and a maximum of 70 pages (including appendices) when the content is more juridical and the family is more complex. Creating a Family Constitution generally requires a communication and work process of 6 to 8 months. It takes time for a consultant to gather information and understand the company. In addition, multiple individual and joint meetings must be held with various members of the family, aligning their professional agendas. In addition, it takes time for family members to agree and commit to the Family Constitution. Often, when the Protocol process takes a long time, it reflects difficulties in reaching agreements and it is never signed. Likewise, the Family Constitution is generally not completed when the family has significant departure conflicts. It is advisable to begin the Protocol process when significant tensions are not present in the family business. Generally, the Protocol includes all the family branches. All relatives who are involved in the firm usually participate in the process and sign the agreement, with the exception of in-laws. The Family Constitution is of no use unless all stakeholders sign the agreement. Generally, in-laws are prevented from working in the company and are excluded from ownership of the firm. However, spouses have a key influence in practice and this should be properly integrated into the agreement. It is advisable to inform in-laws and consider their opinions during the process of developing the Protocol.

\section{Theoretical Framework and Hypotheses}

Considering the previously discussed qualitative information and based on the agency theory, we propose that the implementation of a Family Constitution is positively related to future firm performance. Family Constitutions generally address firm professionalization, promote shareholder agreements and develop structures that promote family communication and cohesion. We argue that addressing these issues reduces agency conflicts and limits the negative interference of SEW aims, which we expect to improve firm performance.

\section{Agency theory}

Prior studies suggest that family firms have distinct corporate governance and are characterized by a significant alignment of management, ownership and control (Fama \& Jensen, 1983; Schulze, Lubatkin, Dino, \& Buchholtz, 2001). Family businesses generally have fewer principal-agent conflicts (shareholders vs. managers) when compared to dispersed ownership firms, because of their prevalent ownership concentration and family participation 
in the top management team (TMT) (Anderson \& Reeb, 2003; La Porta, López de Silanes, \& Shleifer, 1999; Le Breton-Miller \& Miller, 2009). The presence of a family CEO aligns the interests of managers and owners, mitigates agency conflicts and improves corporate governance, which will enhance firm performance (Anderson \& Reeb, 2003; Minichilli, Corbetta, \& MacMillan, 2010; Villalonga \& Amit, 2006). Nevertheless, principal-agent agency costs may be incurred (incentives and monitoring) in the case of family CEOs because of free-riding opportunities that family altruism may provide for family agents and damages derived from nepotism (Van den Berghe \& Carchon, 2003; Zellweger \& Kammerlander, 2015).

Other agency costs may be incurred by family businesses because of principal-principal relationships, such as those arising from majority-minority-owner conflicts or family blockholder conflicts (Morck, Wolfenzon, \& Bernard, 2005; Shleifer \& Vishny, 1997; Zellweger \& Kammerlander, 2015) that negatively will affect performance (Lubatkin, Schulze, Ling, \& Dino, 2005; Sciascia \& Mazzola, 2008). Controlling family shareholders and other family members on the board of directors or on the TMT may take advantage of their superior position and knowledge of the firm to appropriate private benefits of control at the expense of the business and minority shareholders and may even engage in "tunneling" (transferring some assets and profits out of firm) (Grossman \& Hart, 1980; Hoffman, Wulf, \& Stubner, 2014; Johnson, La Porta, Lopez de Silanes, \& Shleifer, 2000; Morck et al., 2005). In the case of non-family minority owners, conflicts may arise when family owners pursue noneconomic goals that minority shareholders consider harmful to their interests, such as appointing unqualified family members to key positions, non-merit based compensation, or strategic decisions that destroy firm value but secure family control (Cruz, Becerra, \& Gomez-Mejia, 2010; Martin, Gomez-Mejia, Berrone, \& Makri, 2016). Additionally, blockholder conflicts may arise within a family blockholder group as the complexity of family ownership increases over time because of possible heterogeneous financial and nonfinancial interests (Gersick, Davis, Hampton, \& Lansberg, 1997; Zellweger \& Kammerlander, 2015). Aligning heterogeneous interests among family blockholders generates agency costs.

Furthermore, family firms may suffer from intra-family agency conflicts of interest that are caused by principal-"super-principal" relationships, which represent conflicts of interest of family owners with the remainder of the family at large (non-shareholders, non-managers, and non-board members) (Villalonga et al., 2015). Family businesses may be faced with specific agency conflicts that can erode firm performance because of the overlap of family, business and ownership. Relatives who do not participate in ownership, management or governance 
and who do not have formal authority in the firm, but have close family relationships with owners and managers, may impede family business decisions and strategies by promoting the recruitment of unqualified family members, supporting suboptimal investments and less risky capital structures, or interfering with family feuds. This unique agency conflict for family firms is more pronounced for second or later generation family firms (Eddleston, Kellermanns, Floyd, Crittenden, \& Crittenden, 2013; Gersick et al., 1997; Lubatkin et al., 2005).

Considering that superior corporate governance is expected to foster improved firm performance (Coles, McWilliams, \& Sen, 2001; Gedajlovic, Lubaktin, \& Schulze, 2004; Nordqvist et al., 2014), we hypothesize that family firms that have established a Family Constitution will experience improved firm performance. Family firms must utilize governance mechanisms to minimize agency costs and subsequently improve firm performance. We propose that a Family Constitution is an appropriate mechanism to reduce agency conflicts. A Family Constitution is the most inclusive of specific family governance mechanisms because it promotes or includes other mechanisms, such as a Family Assembly, a Family Council, shareholders' agreements, and enhances effective communication within and between the family and the firm. A Family Constitution as a rule improves managers' monitoring and promotes the professionalization of the firm because it strengthens corporate governance mechanisms and includes rules for incorporating family members into the company and improves promotional opportunities for non-family agents, all of which are expected to reduce principal-agent conflicts. In addition, a Family Constitution includes shareholder agreements that regulate the execution of voting rights or the transfer of shares within and outside the family and specifies procedures to resolve disputes and provide for arbitration (Chemla, Habib, \& Ljungqvist, 2007; Zellweger \& Kammerlander, 2015). Shareholder agreements for privately held firms (put and call options, rights of first refusal, tag-along rights, drag-along rights, lockout clauses, buyout agreements, and others) constrain renegotiation and maintain the parties' incentives to make the first-best ex ante investments in the firm and precludes ex post transfers from the firm (Chemla et al., 2007). It is expected that these shareholder agreements reduce majority-minority-owners and family blockholder conflicts. Furthermore, a Family Constitution generally promotes communication and transparency between family members and develops governance instruments such as a Family Council, where employed and non-employed family members discuss and agree on corporate and family issues (Van den Berghe \& Carchon, 2003) without introducing new agent tiers and the consequent agency costs (Carney, Gedajlovic, \& Strike, 2014; Child \& Rodrigues, 2003; 
Zellweger \& Kammerlander, 2015). Typical Family Constitution agreements regarding family member employment and family governance limit nepotism, family feuds and the interference of unqualified family members in the business, which will reduce agency conflicts among family owners and family outsiders.

Therefore, based on the above arguments, we propose and test the following hypothesis:

Hypothesis 1: The implementation of a Family Constitution is positively related to future family business performance.

Although the goal of this study is to explore the relationship between implementing a Family Constitution and future firm performance, we are aware that family firms may also pursue family-centered nonfinancial outcomes linked to their SEW (e.g., Berrone, Cruz, \& Gomez-Mejia, 2012; Chrisman, Chua, \& Zahra, 2003; Gomez-Mejia, Haynes, Nuñez, Jacobson, \& Moyano, 2007; Holt, Pearson, Carr, \& Barnett, 2017) that could impact the achievement of the financial goals. However, the negative aspects of SEW, including managerial entrenchment, succession conflicts and dysfunctional relationships (Berrone et al., 2012), are generally addressed in Family Constitutions. We also expect that typical Family Constitution agreements that promote the professionalization of the firm and limit nepotism minimize potential conflicts that arise from preserving internal versus external SEW (Cruz, Larraza-Kintana, Garcés-Galdeano, \& Berrone, 2014; Vardaman \& Gondo, 2014). Shareholder agreements and family cohesion are promoted by Family Constitutions and are expected to help maintain family control and their influence on day-today operations (internal SEW) as well as to preserve the firm's reputation and image (external SEW) (Vardaman \& Gondo, 2014). However, future studies regarding this topic are needed.

\section{Family firm heterogeneity}

Besides agency conflicts proposals, we consider that family firms are not homogeneous entities (García-Álvarez \& López-Sintas, 2001; Westhead \& Howorth, 2007) and explore the moderating factors of the relationship between implementing a Family Constitution and future firm performance. We contemplate that differences among family firms may affect the effectiveness of Family Constitutions. We propose that positive relationship between Family Constitutions and future firm performance will be stronger when the family is more complex. Specifically, we explore family involvement in management (moderating principal-agent conflicts), family ownership structure (moderating principal-principal conflicts) and family firm generation (moderating principal-“super-principal” conflicts). 
Family firms are heterogeneous and differ in terms of family involvement in ownership and management of the business, which varies significantly in family firms (Chua, Chrisman, Steier, \& Rau, 2012; García-Álvarez \& López-Sintas, 2001; Melin \& Nordqvist, 2007; Westhead \& Howorth, 2007). As family involvement in management and ownership evolves, corporate governance requires more formal control systems and structures (Cruz \& Nordqvist, 2012; Nordqvist et al., 2014). In regards to family management involvement, more principalagent conflicts are expected when the firm has a non-family CEO because of their intrinsic potential opportunism that is exacerbated in the case of family nepotism. However, as previously discussed, Family Constitutions generally enhance corporate governance and rules regarding the incorporation of family members, limiting manager opportunism and promoting firm professionalization, which are all expected to improve performance. Non-family CEOs will have fewer free-riding opportunities and incentives for opportunism, due to improvements in firm professionalization and monitoring by family owners that Family Constitution promotes. In addition, feelings of "distributive injustice", which may arise if less competent family agents are promoted (Van den Berghe \& Carchon, 2003), will be reduced. Therefore, we propose that a strong positive relationship exists between Family Constitutions implementation and future firm performance in cases where the firm has a non-family CEO. In regards to the involvement of family ownership, we consider that multiple family owners likely differ in their financial and nonfinancial interests, which potentially leads to family feuds and conflicts (Bertrand, Johnson, Samphantharak, \& Schoar, 2008; Eddleston \& Kellermanns, 2007; Zellweger \& Kammerlander, 2015) that harm firm performance. However, shareholder agreements are typically addressed in Family Constitutions, which protect minority shareholders and prevent blockholder conflicts. Therefore, we expect Family Constitutions to have a more positive effect on performance when family ownership is not concentrated. Hypotheses 2 and 3 specify these proposals:

Hypothesis 2: The positive relationship between the implementation of a Family Constitution and future firm performance is stronger when the firm has a non-family CEO rather than a family CEO.

Hypothesis 3: The positive relationship between the implementation of a Family Constitution and future firm performance is stronger when the firm has multiple family owners rather than concentrated ownership.

In addition, we expect that more complex families (more principal-“super-principal" conflicts) will experience greater utility of implementing a Family Constitution. Specifically, 
we consider that the generational stage of a family firm may influence the potential degree of conflicts and may increase as new generations and extended family join the firm. Foundermanaged firms (first generation) tend to have highly centralized authority that is vested in the founder, which is a unique position that minimizes potential agency problems (Miller \& Le Breton-Miller, 2006; Gedajlovic et al., 2004; Naldi, Chirico, Kellermanns, \& Campopiano, 2015). Second-generation firms are often organized as sibling partnerships and suffer from conflicts that arise because of different values and interests (Eddleston et al., 2013; Gersick et al., 1997; Lubatkin et al., 2005). Formalized governance mechanisms help control potential siblings' power struggles within a family firm. Agency problems increase when there is a consortium of cousins, which is typical for third and beyond generation firms (Gersick et al., 1997; Jafee \& Lane, 2004) because passive family shareholders and different branches generally become involved in the firm, altruistic attitudes decline and extended family influences decisions regarding the firm. Therefore, we expect that the relative usefulness of implementing a Family Constitution may vary depending on the generation that controls the family business. We expect that the positive effects of implementing a Family Constitution are strongest for third generation and beyond family firms, moderate (weaker, but positive) for second-generation firms, and lowest (although positive) for first generation firms. This hypothesis is formally stated as follows:

Hypothesis 4: The positive relationship between the implementation of a Family Constitution and future firm performance is stronger for later-generation firms when compared to earlier-generation firms.

\section{Sample and Sources}

The difficulty of identifying firms that have implemented a Family Constitution presents an obstacle to conducting studies regarding this topic. However, during 2003-2014, certain regions in Spain established support plans for family businesses and provided economic aid specifically for developing Family Constitutions. This financial support typically covers between $30 \%$ and $50 \%$ of the consulting cost and is widely publicized among companies, their associations and consultants. We believe that nearly all of the companies that implemented a Family Constitution in regions that offered public financial support requested this assistance because of its economic relevance and publicity by both regional governments and business consultants. 
After conducting exhaustive searches and requesting formal information from the appropriate authorities, we obtained an annual list of family firms that operate in Spain and received government support to implement a Family Constitution. The database that was used to test the proposed hypotheses includes $265^{3}$ family businesses that implemented a Family Protocol in Spain during 2003-2013.

Sample companies implemented Family Constitutions during 2003-2013. To analyze performance changes of the sample firms, it is necessary to control for this temporal heterogeneity because of the onset of the global financial crisis in Spain in 2007-2008. In addition, high performing firms could be overrepresented in the sample of firms that implemented a Family Constitution. Therefore, to control for potential sample selection bias and the effect of the global financial crisis, we define a control group by using an exhaustive matching procedure. For each of the 265 firms that implemented a Family Constitution, we conducted a manual thorough search for a corresponding family firm in the $\mathrm{SABI}^{4}$ database for a firm that was the most similar in terms of region (to isolate institutional influences), industry, size (number of employees), age (firm foundation date), return on assets and leverage at the beginning of the year that the Family Constitution was implemented. To ensure that the paired company was a family firm, we conducted an exhaustive comparison of the surnames of shareholders, managers and board members for each firm (Spanish individuals use two surnames, the first one name is from their father and the second name is from their mother). We consider that a firm is a family business when the majority of shares are held by relatives who also have a significant presence on the management team and/or board of directors. Finally, we manually verified that a Family Constitution did not exist for the control firms based on three conditions: (1) the firm did not receive any public aid to develop a Family Constitution; (2) the firm is not affiliated with any Family Business Regional Association (all regions have an association); and (3) a lack of any public reference to having a Family Constitution, primarily through the Corporate Web or public registration in the Spanish Public Commercial Register ${ }^{5}$.

\footnotetext{
${ }^{3}$ We previously eliminated 27 companies from the database that received public support in 2014 because the necessary financial data had not been published (two years after the Protocol implementation). We also eliminated 5 companies because we were unable to find a similar control firm in the matching procedure.

${ }^{4}$ SABI (Iberian System of Balance Analysis) is analogous to the European Amadeus database.

${ }^{5}$ It is noteworthy to highlight a law that was passed in Spain in the same year that our database begins (Royal Decree 7/2003), which establishes three optional levels for publicizing Family Constitutions, from simply indicating that a firm has a Family Constitution, to registering its content.
} 
Table 1 summarizes a comparison of the family firms that implemented a Family Constitution and the control group to show that both groups are comparable. Family firms that implemented a Family Constitution represent 50.0 percent of our sample and are equally distributed by region and industry when compared to the firms that did not implement a Family Constitution (control group). There are no statistically significant differences between the company groups by size or age (nor in terms of prior ROA, ROE and leverage as is indicated in Table 2). In addition, family generation distribution is comparable between both groups of firms (we consider 25 years for each generation following Gersick et al., 1997).

Table 1. Descriptive statistics of family firms with Family Constitutions and the control group.

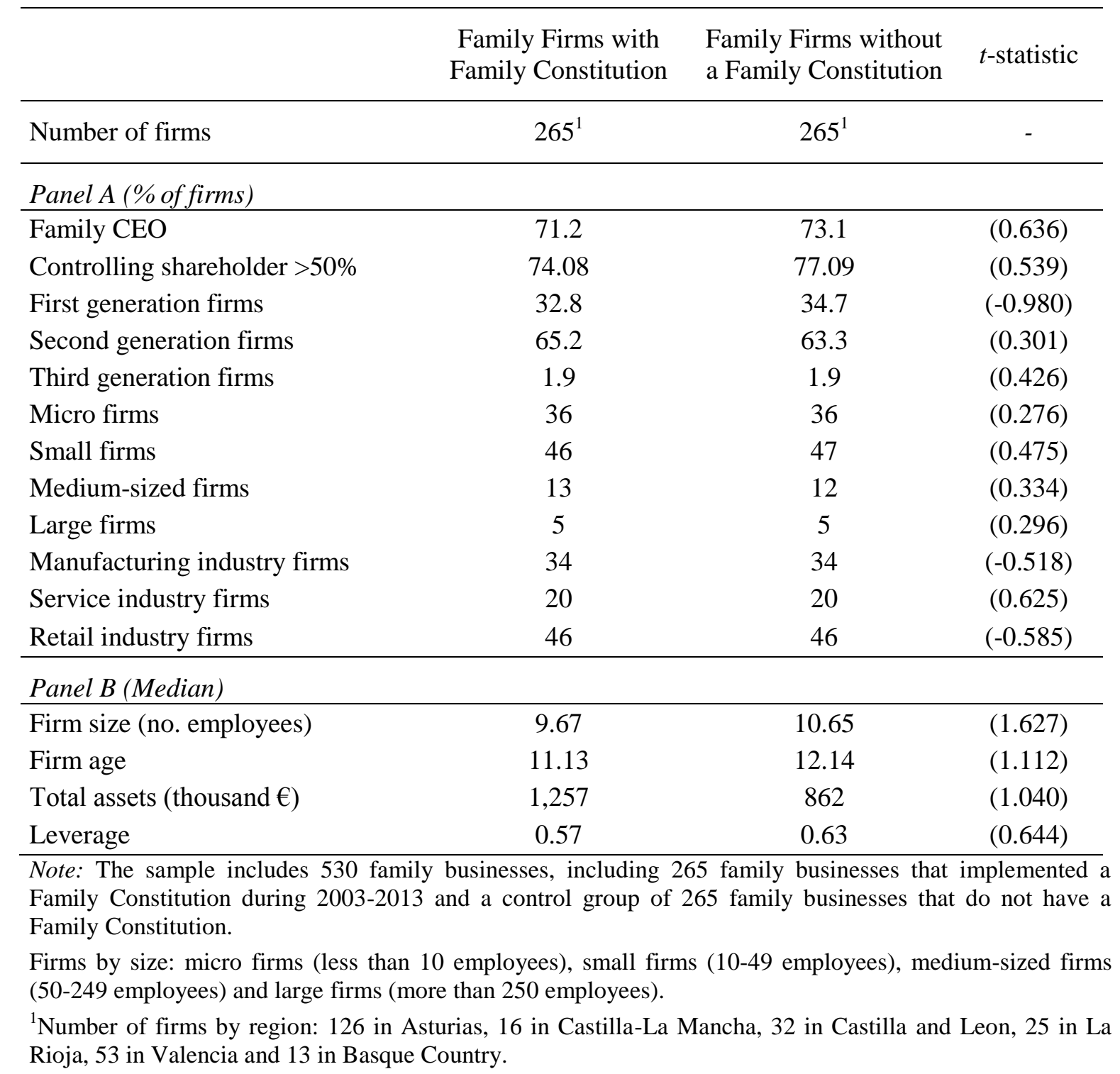


Table 2. Performance and Leverage.

\begin{tabular}{|c|c|c|c|c|c|c|c|c|}
\hline \multicolumn{9}{|c|}{ Panel A: ROA (\%) } \\
\hline \multirow[t]{2}{*}{ Year } & \multicolumn{3}{|c|}{$\begin{array}{c}\text { Firms With } \\
\text { Family Constitution }\end{array}$} & \multicolumn{3}{|c|}{$\begin{array}{c}\text { Firms Without } \\
\text { a Family Constitution }\end{array}$} & \multicolumn{2}{|c|}{ Significance test } \\
\hline & Median & Mean & Deviation & Median & Mean & Deviation & $\mathrm{t}$-test & W-Wilcoxon \\
\hline $\mathrm{t}-2$ & 3.14 & 8.09 & 13.27 & 3.12 & 5.54 & 6.75 & $(0.452)$ & $(0.838)$ \\
\hline $\mathrm{t}-1$ & 3.15 & 4.53 & 12.74 & 3.20 & 5.23 & 7.22 & $(0.584)$ & $(0.354)$ \\
\hline $\mathrm{t}$ & 3.08 & 3.89 & 14.6 & 3.08 & 4.91 & 8.05 & $(0.949)$ & $(0.217)$ \\
\hline$t+1$ & 1.74 & 2.59 & 5.08 & 1.71 & 1.56 & 6.92 & $(0.022)^{* *}$ & $(0.000)^{* * *}$ \\
\hline$t+2$ & 1.26 & 0.40 & 6.38 & 1.23 & 0.69 & 7.45 & $(0.556)$ & $(0.001)^{* *}$ \\
\hline$t+3$ & 1.88 & 2.47 & 11.32 & 1.33 & 2.73 & 8.42 & $(0.998)$ & $(0.727)$ \\
\hline$t+4$ & 1.51 & 1.85 & 8.80 & 1.24 & 3.44 & 8.18 & $(0.280)$ & $(0.490)$ \\
\hline$t+5$ & 1.42 & 0.93 & 11.02 & 1.22 & 0.91 & 7.03 & $(0.223)$ & $(0.258)$ \\
\hline \multicolumn{9}{|c|}{ Panel B: ROE (\%) } \\
\hline \multirow[t]{2}{*}{ Year } & \multicolumn{3}{|c|}{$\begin{array}{c}\text { Firms With } \\
\text { Family Constitution }\end{array}$} & \multicolumn{3}{|c|}{$\begin{array}{c}\text { Firms Without } \\
\text { a Family Constitution }\end{array}$} & \multicolumn{2}{|c|}{ Significance test } \\
\hline & Median & Mean & Deviation & Median & Mean & Deviation & t-test & W-Wilcoxon \\
\hline $\mathrm{t}-2$ & 6.27 & 7.96 & 13.61 & 4.83 & 8.10 & 14.72 & $(0.514)$ & $(0.223)$ \\
\hline $\mathrm{t}-1$ & 7.50 & 11.30 & 14.49 & 6.83 & 10.16 & 15.82 & (0.444) & $(0.653)$ \\
\hline $\mathrm{t}$ & 7.30 & 10.88 & 16.03 & 5.45 & 8.25 & 14.45 & $(0.002)^{* * *}$ & $(0.001)^{* * *}$ \\
\hline$t+1$ & 8.03 & 9.70 & 41.25 & 4.16 & 6.68 & 13.41 & $(0.431)$ & $(0.001)^{* * *}$ \\
\hline$t+2$ & 7.42 & 9.98 & 19.18 & 3.45 & 5.45 & 13.51 & $(0.013)^{* * *}$ & $(0.001)^{* * *}$ \\
\hline$t+3$ & 3.86 & 5.17 & 17.61 & 2.91 & 1.17 & 20.21 & $(0.578)$ & $(0.727)$ \\
\hline $\mathrm{t}+4$ & 3.47 & 3.35 & 18.43 & 1.98 & 1.06 & 9.22 & $(0.280)$ & $(0.490)$ \\
\hline$t+5$ & 4.36 & 6.02 & 40.85 & 3.20 & 2.74 & 15.39 & $(0.510)$ & $(0.258)$ \\
\hline
\end{tabular}

Panel C: Leverage

\begin{tabular}{ccccccccl}
\hline & \multicolumn{3}{c}{ Firms With } & \multicolumn{3}{c}{ Firms Without } & \multicolumn{2}{c}{ Significance test } \\
Year & \multicolumn{3}{c}{ Family Constitution } & \multicolumn{2}{c}{ a Family Constitution } & \multicolumn{2}{c}{ (-test } & W-Wilcoxon \\
\hline t-2 & 0.53 & 0.57 & 0.31 & 0.46 & 0.43 & 0.31 & $(0.247)$ & $(0.328)$ \\
$\mathrm{t}-1$ & 0.57 & 0.55 & 0.31 & 0.63 & 0.61 & 0.32 & $(0.644)$ & $(0.376)$ \\
$\mathrm{t}$ & 0.54 & 0.52 & 0.27 & 0.59 & 0.56 & 0.33 & $(0.367)$ & $(0.617)$ \\
$\mathrm{t}+1$ & 0.55 & 0.52 & 0.30 & 0.51 & 0.53 & 0.34 & $(0.041)^{* *}$ & $(0.070)^{* * *}$ \\
$\mathrm{t}+2$ & 0.53 & 0.51 & 0.28 & 0.49 & 0.51 & 0.36 & $(0.033)^{* *}$ & $(0.043)^{*}$ \\
$\mathrm{t}+3$ & 0.51 & 0.49 & 0.29 & 0.45 & 0.49 & 0.35 & $(0.030)^{* *}$ & $(0.087)^{*}$ \\
$\mathrm{t}+4$ & 0.49 & 0.54 & 0.56 & 0.43 & 0.49 & 0.37 & $(0.250)$ & $(0.423)$ \\
$\mathrm{t}+5$ & 0.48 & 0.47 & 0.27 & 0.39 & 0.49 & 0.52 & $(0.866)$ & $(0.093)^{*}$ \\
\hline
\end{tabular}

Note: $\mathrm{t}=$ year the Family Constitution was implemented. For year $\mathrm{t}-2$ to $\mathrm{t}+2$, the sample includes 530 family businesses, including 265 family businesses that implemented a Family Constitution during 2003-2013 and a control group of 265 family businesses that did not implement a Family Constitution. For year $t+3$ the sample includes 438 firms, 432 firms for year $t+4$ and 410 firms for year $t+5$ (half of these firms implemented a Family Constitution and the other half do not have a Family Constitution).

$*, * *$ and $* * *$ indicate significance at the $10 \%, 5 \%$ and $1 \%$ levels, respectively. 
Table 2 describes the performance of the companies that implemented a Family Constitution and the control group including ROA, ROE and leverage ${ }^{6}$ using data from two years prior to the implementation of the Protocol to five years after the implementation. None of the companies in our sample are listed on the stock market, which is the case for the majority of Spanish companies; therefore, market value measures are not included in the study. In addition, we conducted a statistical analysis of sub-samples based on the differences between medians and means (non-parametric W-Wilcoxon median test and t-test of equal means for related samples). We also conducted a matched-pair analysis. According to the design of the control group, there are no significant differences in ROA, ROE or leverage for both groups of firms prior to the implementation of the Family Constitutions. This preliminary analysis indicates that family firms that implement a Family Protocol achieve significantly higher ROA one year and two years after the implementation than firms in the control group (firms that did not implement a Family Protocol). In addition, ROE is higher for family firms after they implemented a Family Constitution. The matched-pair analysis reached the same conclusion. Next, we performed a multivariate analysis to control spurious relationships and consider potential moderating factors.

\section{Multivariate Analysis}

\section{Methodology}

To test the proposed hypotheses regarding the positive relationship between the implementation of a Family Constitution and future firm performance, while considering the moderating role of family management, family ownership and the generation in control, we estimate multivariate regression models and control for firm-specific variables. The regression equation that we test is calculated as follows:

$$
\begin{aligned}
\triangle R O A_{i t+2}= & \alpha_{i}+\beta_{1 i} \text { FamilyConstitution }_{i t}+\beta_{2 i} \text { FamilyConstitution }_{i t} * \text { Non-FamilyCEO }_{i t}+\beta_{3 i} \text { Non-FamilyCEO }_{i t}+ \\
& \beta_{4 i} \text { FamilyConstitution }_{i t} * \text { MultipleFamilyOwners }_{i t}+\beta_{5 i} \text { MultipleFamilyOwners }_{i t}+ \\
& \beta_{6 i} \text { FamilyConstitution }_{i t} * \text { Generation }_{i t}+\beta_{7 i} \text { Generation }_{i t}+\beta_{8 i} \text { AROAsector }_{i t+2}+\beta_{9 i} \text { ROA }_{i t-1}+\beta_{10 i} \text { FirmSize }_{i t}+ \\
& \beta_{11 i} \text { Leverage }_{i t}+\beta_{12 i} \text { IndustryVariables }_{i t}+\varepsilon_{i t}
\end{aligned}
$$

where $i$ represents the firm, $t$ represents time, and $\varepsilon_{i t}$ denotes the error term. We control autocorrelation using the Durbin-Watson statistic test. To mitigate concerns regarding

\footnotetext{
${ }^{6} R O A$ is defined as earnings before interest, tax, depreciation, and amortization (EBITDA), divided by total assets; $R O E$ is defined as net profit divided by equity; and Leverage is defined as total liabilities divided by total assets.
} 
multicollinearity, all interactions were entered separately into the regression equation. All hypotheses were tested using hierarchical regression analysis.

\section{Dependent variable}

$\triangle R O A$. To test the potential positive relationship between the implementation of a Family Constitution and future firm performance, we define growth in ROA two years after the implementation of a Family Constitution for each firm as the dependent variable, which is calculated as $\left(\mathrm{ROA}_{t+2}-\mathrm{ROA}_{t}\right)$ divided by $\mathrm{ROA}_{t}$. ROA is preferred to ROE because it is the root of firm performance and allows better isolation of the effect of leverage decisions. We incorporated a delay of two years to allow time for the effects of the Protocol to occur, but not too long for other relevant facts to affect the analysis (in addition to losing observations in our database).

\section{Family Constitution and moderating variables}

Family Constitution is the key explanatory variable that is tested in our study ${ }^{7}$. Family Constitution is defined as a dummy variable that takes the value of 1 if the firm has implemented a Family Constitution in any year during the period 2003-2013 and zero otherwise. Hypothesis 1 proposes that a positive relationship exists between the implementation of a Family Constitution and future firm performance.

In addition, we included the following variables and their multiplicative with the Family Constitution variable to test their potential moderating effects on the implementation of a Family Constitution as proposed in Hypotheses 2 through 4:

Non-family CEO. We expect greater utility of the Family Constitution when agentprincipal conflicts are greater, thus when the firm has a non-family CEO (Hypothesis 2). To identify the existence of a CEO that is a member of the family in each sample firm, we

\footnotetext{
${ }^{7}$ To explore the characteristics and similarity of the Family Constitutions, a postal survey was mailed to the 265 firms in the database that implemented Family Constitutions (29 firms responded, which resulted in a $10.9 \%$ response rate after a second mailing). Firms confirm that their Family Constitutions address agreements regarding management, ownership and the governance of the company. It highlights that $96 \%$ of the Family Protocols address the organization of a Family Council and the professionalization of the company, 93\% address the incorporation of family members into the company and include clauses regarding the transfer of shares and $89 \%$ of the Protocols address the succession of management. They emphasize the ability of the implementation of the Protocol to maintain control of the firm, favor its continuity, improve the transparency between the firm and the family and also acknowledge its ability to reduce conflicts between family members.

The median number of pages of a Family Constitution is 41 (minimum 19 and maximum 63), the median number of signers is 5 (minimum 2 and maximum 21), the average time for completion of the document is 10 months, all family members over 18 years of age sign these agreements and a family member was only slightly involved in the process for $37 \%$ of the cases. In $44 \%$ of the cases, firms are between the first and the second generation, in $96 \%$ of the cases a family member is CEO of the firm and on average the majority shareholder owns $51 \%$ of the firm.
} 
manually check managers' board composition and match their surnames with the surnames of the group of family owners. The variable Non-family CEO was coded as 1 when a firm has a non-family CEO and 0 for firms that hired a CEO who is a member of the owning family.

Multiple family owners. We expect that Family Constitutions are more useful when family shareholders conflicts exist (Hypothesis 3). We defined a dummy variable that takes the value of 1 if more than one family shareholder exists and 0 otherwise (one majority shareholder owns $100 \%$ of the firm).

Generation. We consider the moderating role of the generation that controls the firm in the relationship between the implementation of a Family Constitution and future firm performance because of the expectation of increased conflicts between the principals and the remainder of the family in later generations (Hypothesis 4). We define the dummy variable Generation, which takes the value of 1 for first-generation firms (founders), the value of 2 for second-generation firms and the value of 3 for third and beyond generation firms. In addition, we consider alternative definitions such as the logarithm of firm age.

\section{Control variables}

$\triangle R O A$ sector. We included an explanatory variable, growth in industry ROA two years after the implementation of a Family Constitution $(t+2)$, to isolate the effect of external factors that are linked to the economy and industry evolution on firm performance growth. Family firms in our database implemented their Family Constitutions in different years during 2003-2013. This time frame includes the economic crisis started in 2007-2008. For each firm, we calculated the ratio $\left(\right.$ ROAsector $_{\mathrm{t}+2}-$ ROAsector $_{\mathrm{t}}$ ) divided by ROAsector $\mathrm{r}_{\mathrm{t}}$. ROAsector is measured each year as the median return on assets of firms that have the same two-digit NACE code.

$R O A_{t-1}$. To refine the data after the matching procedure, we included ROA one year prior to the implementation of a Family Constitution ( $t-1)$ in the regressions to control for prior firm performance, which could influence the decision to execute a Family Constitution.

Firm size. The resource-based view indicates that less formalized and poor professional practices occur in small firms (De Kok, Uhlaner, \& Thurik, 2006; Penrose, 1959). Potential greater benefits of implementing a Family Constitution are controlled for small companies. We measured size as the logarithm of the number of employees (logEMP) (to reduce heteroscedasticity concerns because of the highly skewed distribution of this variable). We consider alternative variables, such as the logarithm of total assets and dummy variables with different cut-offs of employment level. 
Leverage. Debt may act as a device to discipline managers by positively influencing performance (Jensen, 1986). We included firm leverage, which is defined as total liabilities divided by total liabilities plus net equity.

Industry. We grouped sample firms into three industry groups, manufacturing, services and retail (Chrisman, Kellermanns, Chan, \& Liano, 2010; Hoffman et al., 2014), according to the primary activity of the company (two-digit NACE code). We define three dummy variables, one for each sector, and include two of these variables in the regression analysis (manufacturing and retail).

Table 3 provides the correlation matrix, mean and standard deviation of the variables that are included in the regression analyses.

\section{Results}

We tested the proposed hypotheses by conducting a hierarchical regression analysis. The results are provided in Table 4. Model 1 only included the control variables, Model 2 added the Family Constitution variable, Model 3 tested the moderating effects with the multiplicative variables of Family Constitution and Model 4 only included the significant explanatory variables from the prior models. We include the standardized beta coefficients (this is why no coefficient is obtained for the constant term) to allow comparisons of the explanatory power of different variables.

Hypothesis 1 proposes that the implementation of a Family Constitution is positively related to future family firm performance. The results of the estimated Model 2 support Hypothesis 1 because the dummy variable that indicates that the family firm implemented a Family Constitution is statistically significant as a determinant of firm performance growth with a positive sign $(\beta=0.102)$. Firms that dedicated the time and effort to develop a Family Constitution achieved greater firm performance growth. We observe having several family shareholders (MultipleFamilyOwners), rather than having a single majority owner, has a positive influence on firm performance growth $(\beta=0.086)$. Prior return on assets $\left(R O A_{t-1}\right)$ is also positive and significant $(\beta=0.101)$ in all the models but is not correlated with the other explanatory variables. The remaining control variables are not statistically significant. In this regard and considering the model explanatory power tests, we again note that the dependent variable is ROA growth, which is calculated for different times during the 2003-2013 period, depending on the year that the Family Constitution was implemented. 
Table 3. Correlation Matrix, means and standard deviation.

\begin{tabular}{|c|c|c|c|c|c|c|c|c|c|c|c|c|c|}
\hline & Mean & SD & 1 & 2 & 3 & 4 & 5 & 6 & 7 & 8 & 9 & 10 & 11 \\
\hline 1. $\triangle \mathrm{ROA}$ & 2.24 & 3.67 & & & & & & & & & & & \\
\hline 2. Family Constitution & 0.50 & 0.50 & $0.104^{*}$ & & & & & & & & & & \\
\hline 3. Non-family CEO & 0.16 & 0.37 & 0.051 & $0.151 * *$ & & & & & & & & & \\
\hline 4. Multiple family owners & 0.76 & 0.42 & 0.083 & -0.007 & -0.008 & & & & & & & & \\
\hline 5. Generation & 1.72 & 0.48 & 0.017 & 0.013 & 0.035 & -0.014 & & & & & & & \\
\hline 6. $\triangle \mathrm{ROAsector}$ & 0.20 & 0.83 & 0.019 & 0.027 & $0.129 * *$ & -0.082 & 0.021 & & & & & & \\
\hline 7. $\mathrm{ROA}(\mathrm{t}-1)$ & 4.88 & 9.98 & $0.098^{*}$ & -0.018 & -0.014 & 0.023 & -0.063 & 0.033 & & & & & \\
\hline 8. Firm size & 2.96 & 1.20 & 0.040 & $-0.108^{*}$ & $0.144 * *$ & -0.032 & 0.081 & $0.187 * *$ & -0.035 & & & & \\
\hline 9. Leverage & 0.56 & 0.35 & 0.030 & 0.070 & 0.051 & -0.055 & -0.021 & -0.061 & -0.009 & -0.045 & & & \\
\hline 10. DummyIND (Manufact.) & 0.25 & 0.43 & 0.026 & 0.017 & 0.008 & -0.063 & -0.000 & $0.442 * *$ & 0.053 & -0.017 & $-0.102 *$ & & \\
\hline 11. DummyIND (Services) & 0.24 & 0.42 & -0.066 & -0.040 & -0.062 & -0.060 & $-0.153 * *$ & $-0.522 * *$ & 0.044 & $-0.136^{* *}$ & $0.116 * *$ & $-0.333 * *$ & \\
\hline 12. DummyIND (Retail) & 0.15 & 0.36 & -0.019 & 0.002 & -0.081 & 0.056 & 0.015 & $-0.132 * *$ & -0.019 & -0.063 & $0.092 *$ & $-0.255^{* *}$ & $-0.246 * *$ \\
\hline
\end{tabular}

Note: The sample comprises 530 family businesses, including 265 family businesses that implemented a Family Constitution during $2003-2013$ and a control group of 265 family businesses that do not have a Family Constitution.

$*$, and $* *$ indicate correlations significance at $\mathrm{p}<.05$ and $\mathrm{p}<.01$, respectively. 
Model 3 illustrates the nuances of the relationship between implementing a Family Constitution and firm performance growth. We included the multiplicative variables of implementing a Family Constitution and having a non-Family CEO, multiple family owners, and older generations, to test Hypothesis 2 through 4, respectively. We observe that the positive relationship between the implementation of a Family Constitution and firm performance growth depends on family involvement in management and ownership and on family complexity. In accordance with Hypotheses 2, the variable FConstitution*NonFamilyCEO is statistically significant and positive $(\beta=0.127)$, which indicates that the positive relationship between the implementation of a Family Constitution and firm performance growth is stronger when the firm has a non-family CEO and conflicts with family owners are more likely. The positive and statistically significance of the multiplicative variable FConstitution*MultipleFamilyOwners $(\beta=0.309)$ is in agreement with Hypotheses 3 , in accordance with a greater utility of a Family Constitution for firm performance improvement when multiple family shareholders exist rather than one unique owner and blockholder conflicts may occur. This multiplicative variable has the highest standardized beta coefficient. The multiplicative variable FConstitution*Generation is also positive and significant $(\beta=0.089)$ and indicates that later-generation family firms (more complex family) that implement a Family Constitution experience higher growth in firm performance. These results support Hypotheses 2, 3 and 4 regarding the greater utility of the Family Constitution for performance improvement when a family firm has a non-family CEO, when multiple family owners exist and when later generations control the firm.

The F-statistic that is associated with the set of covariates is significant at the .10 level in model 2 and significant at the 0.01 level in models 3 and 4. A Durbin-Watson test was conducted to detect the presence of autocorrelation in the residuals (1.3). Multicollinearity is not a concern in the regression analysis. Model 4 provides the statistically significant explanatory variables. 
Table 4. Regression analysis: growth in ROA two years after implementing a Family Constitution.

\begin{tabular}{|c|c|c|c|c|}
\hline & Model 1 & Model 2 & Model 3 & Model 4 \\
\hline \multirow[t]{2}{*}{ Family Constitution } & & 0.102 & 0.123 & \\
\hline & & $(2.313)^{* *}$ & $(0.867)$ & \\
\hline \multirow[t]{2}{*}{ Non-family CEO } & 0.044 & 0.027 & 0.030 & \\
\hline & $(0.993)$ & $(0.612)$ & $(0.684)$ & \\
\hline \multirow[t]{2}{*}{ Multiple family owners } & 0.085 & 0.086 & 0.094 & 0.089 \\
\hline & $(1.938)^{*}$ & $(1.964)^{* *}$ & $(2.165)^{* *}$ & $(2.082)^{* * *}$ \\
\hline \multirow[t]{2}{*}{ Generation } & 0.020 & 0.019 & 0.007 & \\
\hline & $(0.469)$ & $(0.430)$ & $(0.164)$ & \\
\hline \multirow[t]{2}{*}{ FConstitution*Non-family CEO } & & & 0.127 & 0.114 \\
\hline & & & $(2.240)^{* *}$ & $(2.055)^{* *}$ \\
\hline \multirow[t]{2}{*}{ FConstitution*Multiple family owners } & & & 0.309 & 0.184 \\
\hline & & & $(2.085)^{* *}$ & $(3.308)^{* * *}$ \\
\hline \multirow[t]{2}{*}{ FConstitution*Generation } & & & 0.089 & 0.095 \\
\hline & & & $(2.034)^{* *}$ & $(2.221)^{* *}$ \\
\hline \multirow[t]{2}{*}{$\Delta$ ROAsector } & -0.001 & -0.005 & -0.012 & \\
\hline & $(-0.024)$ & $(-0.099)$ & $(-0.246)$ & \\
\hline \multirow[t]{2}{*}{$\mathrm{ROA}(\mathrm{t}-1)$} & 0.099 & 0.101 & 0.107 & 0.104 \\
\hline & $(2.272)^{* *}$ & $(2.330)^{* *}$ & $(2.480)^{* *}$ & $(2.428)^{* *}$ \\
\hline \multirow[t]{2}{*}{ Firm size } & 0.039 & 0.053 & 0.064 & \\
\hline & $(0.867)$ & $(1.171)$ & 1.394 & \\
\hline \multirow[t]{2}{*}{ Leverage } & 0.041 & 0.035 & 0.025 & \\
\hline & $(0.930)$ & $(0.797)$ & $(0.580)$ & \\
\hline \multirow[t]{2}{*}{ DummyIND (Manufact.) } & 0.024 & 0.024 & 0.028 & \\
\hline & $(0.471)$ & $(0.469)$ & $(0.548)$ & \\
\hline \multirow[t]{2}{*}{ DummyIND (Retail) } & -0.013 & -0.014 & -0.010 & \\
\hline & $(-0.290)$ & $(-0.308)$ & $(-0.227)$ & \\
\hline R-squared & 0.023 & 0.033 & 0.055 & 0.048 \\
\hline F-test & 1.346 & 1.756 & 2.299 & 5.261 \\
\hline t-test (Sig.) & 0.210 & 0.066 & 0.006 & 0.000 \\
\hline Durbin-Watson & 1.317 & 1.333 & 1.323 & 1.314 \\
\hline
\end{tabular}

Note: The sample comprises 530 family businesses, including 265 family businesses that implemented a Family Constitution during 2003-2013 and a control group of 265 family businesses that do not have a Family Constitution.

Standardized coefficients (t-value in parentheses).

$*, * *$ and $* * *$ indicate significance at the $10 \%, 5 \%$ and $1 \%$ levels, respectively. 


\section{Conclusion and Discussion}

It is challenging for family firms to find the right governance mechanisms to maximize potential advantages and overcome disadvantages that result from different degrees of family involvement in the business (Nordqvist et al., 2014). Although the corporate governance structures of family businesses have been thoroughly analyzed, particularly the board of directors (Bammens, Voodeckers, \& Van Gils, 2011), the same has not occurred for parallel corporate governance processes including norms of legitimacy and authority relationships (Nordqvist et al., 2014). Proper family governance affects the success of a family business (Kammerlander, Sieger, Voordeckers, \& Zellweger, 2015). We contribute to the study of this topic by examining the Family Constitution, which has rarely been empirically studied, despite its importance in consultancy. A Family Constitution (or Protocol) executes an internal communication process to formalize agreements among family members and delineate their relationships with the family firm.

\section{Conclusions}

Based on agency theory, we propose that the implementation of a Family Constitution is positively related to future firm performance. In-depth interviews that we conducted with specialized family firm consultants confirmed that generally, a Family Constitution develops norms and agreements to avoid conflicts that may be caused by overlap between family members, ownership and/or management interests. A Family Constitution addresses terms regarding family members incorporation into the firm, multiple family shareholders agreements and shapes the Family Council. We expect that these agreements enhance the management monitoring and firm professionalization (mitigating principal-agent conflicts), limit conflicts between shareholders (mitigating principal-principal conflicts) and reduce the negative interference of family in the management of the firm (mitigating principal-"superprincipal" conflicts) (Carney et al., 2014; Child \& Rodrigues, 2003; Zellweger \& Kammerlander, 2015). To test these proposals, we compared a database of family businesses that operate in Spain and had established a Family Constitution during 2003-2013 to a control group of family businesses that did not implement a Family Protocol. Our results indicate that a positive relationship exists between the implementation of a Family Constitution and future firm performance, particularly when the family firm has a non-family CEO, when the firm has multiple family owners and when later generations control the firm. 


\section{Contributions}

Our study contributes to theory and extant literature. First, we contribute to agency theory in general and corporate governance family firm research in particular by discussing understudied types of agency costs (Villalonga et al., 2015; Zellweger \& Kammerlander, 2015), including the principal-agent conflict in family firms, family blockholder conflicts and family owners vs. family-at-large agency conflict. We respond to calls for research regarding family agency costs and corporate governance by Carney et al. (2014) and explore nonorganizational solutions such as Family Constitutions to mitigate family blockholder conflicts that are suggested by Zellweger and Kammerlander (2015). In addition, we answer a call for research by Villalonga et al. (2015) regarding the conflict between family shareholders and the family at large about family governance mechanisms to mitigate agency problems. This study enhances our understanding of family business governance and the implications of the agency theory regarding formal corporate governance mechanisms by showing that a Family Constitution represents a relevant corporate governance mechanism. Although Family Constitutions are typical of family businesses, the usefulness of some of their components to mitigate principal-agent and principal-principal conflicts may be extended to non-family businesses. Business research in general should take into account that, in addition to the development of corporate governance, firm performance may also improve by promoting firm professionalization and shareholder agreements (such as put and call options, rights of first refusal, tag-along rights, drag-along rights, lockout clauses or buyout agreements).

Second, we contribute to relatively recent studies regarding family firm heterogeneity (Chua et al., 2012; Cruz \& Nordqvist, 2012; García-Álvarez \& López-Sintas, 2001; Westhead \& Howorth, 2007). Appropriate governance mechanisms for achieving performance goals may vary among different types of family firms (Nordqvist et al., 2014). We note the moderating roles of family involvement in management and ownership and the family generation. The positive relationship between the implementation of a Family Constitution and future firm performance is stronger when the firm has non-family management, has nonconcentrated family ownership and later generations control the firm.

Third, our research contributes to extant literature regarding family firms by being one of few studies to concentrate specifically on the Family Constitution and by being the only study, to our knowledge, regarding the relationship between a Family Constitution and firm performance (Gersick \& Feliu, 2014, note this). We address this lack of empirical research by performing a quantitative analysis and conducting exploratory in-depth interviews, which 
provide interesting data regarding the characteristics of Family Constitutions. Clearly, additional studies are needed. Nevertheless, our results provide an empirical base that highlights the interest in this line of research.

Fourth, this study contributes to family firm literature that examines family firm performance and moderating factors because it is the first empirical work to analyze the relationship between firm performance and the Family Constitution. Our results extend prior studies regarding family firm performance by showing that a positive relationship exists between Family Constitution agreements and future firm performance.

Finally, we contribute to extant literature by exploring privately held family firms. Mazzi (2011) recognized that this topic needed additional analysis. Studies regarding private family firms are relatively rare when compared to the large number of studies regarding publicly listed family firms (Mazzi, 2011). Empirical studies reporting that family firm performance declines after the founder's generation (Pérez-González, 2006; Villalonga \& Amit, 2006) are based on samples of large and listed firms; therefore, survivor bias is inherent because analyzed first-generation family businesses are the very top performers among all firstgeneration family firms (Amit \& Villalonga, 2014). We contribute by enhancing our understanding of family businesses by primarily focusing our empirical analysis on privately held small companies.

\section{Practical implications}

This study has practical implications for family businesses and their consultants. Specifically, our results highlight the importance of negotiations and communication that ultimately lead to the implementation of a Family Constitution. Even during times of economic crisis, we observed that companies that had implemented a Family Protocol reported higher levels of firm performance growth. By showing that the implementation of a Family Constitution is positively related to future firm performance, our study provides evidence for families to engage in this complex and lengthy communication and agreements process with determination. Furthermore, implementing a Family Constitution may be a positive signal that can be used by financial institutions, suppliers, customers and other stakeholders.

\section{Limitations and future research}

This study includes certain limitations, some of which provide insights for future research. First, the data we used for the multivariate analysis are quantitative in nature. This allowed us to analyze the impact of developing a Family Constitution on achieving firm goals in terms of 
performance outcomes. However, a qualitative approach may generate a better understanding of the drivers and characteristics of successful Family Constitutions. We believe that case studies represent an appropriate research methodology to conduct in depth study regarding the complex process of developing Family Protocols. Furthermore, our results suggest that each generation of a family firm should be studied on its own terms with respect to the Family Constitution. This type of research may be of interest considering non-economic goals (Chrisman, et al., 2003) and SEW (Gomez-Mejia et al., 2007). In addition to financial outcomes, a Family Constitution may contribute to achieving family non-financial goals such as improving SEW. How does a Protocol impact the various dimensions of SEW? Measuring SEW dimensions is an outstanding challenge and requires research methodologies such as surveys, content analysis, laboratory experiments, and case studies (Berrone et al., 2012). In this regard, the measures that were proposed by Berrone et al. (2012) in the FIBER dimensions and the measure that were proposed by Holt et al. (2017) in their family firm outcomes (FFO) model can serve as a guide. In addition, future research could more comprehensively analyze the relative weight of the effects on principal-agent conflicts (professionalization), majority-minority conflicts, blockholder conflicts (shareholders agreements), principal-“super-principal” conflicts (Family Council) and the reinforcement of positive internal and external SEW for the firm. In addition, it would be of interest to investigate the potential advantage of Family Constitutions to avoid double-agency costs. Double-agency costs may emerge when families establish intermediate organizations such as a family office or a family trust to limit negative consequences of blockholder conflicts (Carney et al., 2014; Child \& Rodrigues, 2003; Zellweger \& Kammerlander, 2015). These organizational solutions generate agency costs to aligning the interests of intermediary agents who represent family owners and monitor other agents (firm managers) (Zellweger \& Kammerlander, 2015). A Family Constitution may avoid the interposition of the above mentioned intermediate organizations.

Clearly, our analysis is limited to a sample of family firms from Spain and therefore, we only considered one institutional environment. Future studies may expand knowledge by studying other countries. An even more interesting extension may be to investigate the influence that institutions exert on the governance structures and processes of family firms (Leaptrott, 2005; Melin \& Nordqvist, 2007; Nordqvist \& Melin, 2002), particularly, the Family Constitution. In this regard, institutional theory offers an appropriate framework (Fiss, 2008; Nordqvist \& Melin, 2002). The institutional context includes regulatory, normative and cultural arrangements that stimulate, enforce, and limit economic and social activities and the 
actions of an organization (Berrone \& Gomez-Mejia, 2009; Fang, Memeli, Chrisman, \& Welsh, 2012). Family firms receive advice from formal advisors (Strike, 2012), organizations, networks (Melin \& Nordqvist, 2007), and professional associations (Greenwood, Suddaby, \& Hinings, 2002; Parada, Nordqvist, \& Gimeno, 2010) that prescribe best corporate governance practices and foster specific family firm values (Parada et al., 2010). Do the differences in institutional environments determine the implementation, characteristics or usefulness of Family Constitutions? In addition to academics and practitioners, this type of research would be of interest to policymakers and institutions.

Our database includes a set of firms that received public funding to implement a Family Constitution. Although we conducted an exhaustive matching procedure to define the control group, we did not determine whether these firms were top performers compared to the entire population of family businesses in Spain. The matching procedure allowed us to control for this eventuality because the control group of firms that did not implement a Family Protocol had similar prior performance. However, future studies could consider research questions such as the following: What drives family businesses to develop a Family Constitution? Are these a special type of family businesses? How effective are different agreements that are included in Family Constitutions? In addition, eighty-two percent of our database is made up of micro and small businesses. This underrepresentation of large firms has hindered the analysis of additional hypotheses besides the potential reduction in agency conflicts, such as the potential positive effects for small family firms of implementing a Family Constitution. A Family Protocol generally promotes firm professionalization and thus "best performance practices", through the use of business plans, managing structures and more formal decisionmaking (De Kok, Uhlaner, \& Thurik, 2006; Penrose, 1959). Family Constitution implementation might therefore have a greater influence on firms that previously lacked such practices, which are likely to be small firms. The positive relationship between implementation of a Family Constitution and future firm performance might be stronger for smaller firms than for larger firms.

More longitudinal studies are also needed to better understand the long-term influence of Family Constitutions. Our multivariate analysis shows that family businesses that implemented a Family Constitution had significantly improved performance within two years after implementation. Nevertheless, although multiple factors should be controlled in the analyses, new research questions arise regarding the longer term. Is the positive relation between Family Constitution and firm performance maintained over time? Or does it decrease over the years, as the univariate analysis seems to point out? Which new institutions 
established after implementation of the Family Constitution actually continue to function in later years? Moreover, it would be interesting to analyze the varied success of different Family Protocols in the long-term. For example, some families periodically celebrate their Family Protocol, while in other cases it never becomes effective. Again, studying the cases of firms whose Family Protocol is successful would be an interesting line of research.

Further research might find it interesting to examine more nuances of family heterogeneity (Jaskiewicz, Combs, Shanine \& Kacmar, 2017) and of Family Constitutions. In the same way that research on family businesses has evolved from comparing family and nonfamily firms to focus on family business heterogeneity, this new research topic, in addition to comparing family firms with and without a Family Constitution, should also study the variability of Family Constitutions. Do all Family Constitutions include shareholder agreements, develop firm professionalization and a Family Council, and have a similar level of detail and similar length? Several aspects may be critical in the Family Constitution's influence on firm performance, such as the detail of the agreements, differences in family members' effective involvement in the Family Constitution process and their different perceptions of it, the number of owners, the number of family branches, and size and type of family. A qualitative research could consider the relevance of the various dimensions of families (structures, functions, interactions, and events), including family communication patterns, parenting styles, family life cycles, and others (Jaskiewicz \& Dyer, 2017). Moreover, in contrast with an over-optimistic view of Family Constitution effects, it would also be interesting to analyze potential negative consequences and bad practices in the implementation of such a Constitution.

We believe that there is considerable scope for future research on this topic. More research is needed to better understand how to develop useful Family Constitutions for family businesses that are at different generational stages. We trust that this study will encourage family firm scholars to develop future studies regarding the topic of Family Constitutions.

\section{Acknowledgments}

We acknowledge the constructive comments and suggestions received from Prof. Francesco Chirico (JIBS), the associate editor of FBR, Justin W. Webb, and the three anonymous reviewers, which have greatly improved the article. 


\section{Declaration of Conflicting Interests}

The author(s) declared no potential conflicts of interest with respect to the research, authorship, and/or publication of this article.

\section{Funding}

The authors disclosed receipt of the following financial support for the research, authorship, and/or publication of this article: This work has received financial support from the Spanish Ministry of Economy and Competitiveness/FEDER (Project ECO2015-66184-R), the Spanish Economy Competitiveness Ministry (ECO2012-31772), and from the Family Business Chair of Oviedo University (supported by AEFAS, FADE, and IEF in Spain).

\section{References}

Amit, R., \& Villalonga, B. (2014). Financial performance of family firms. In The SAGE Handbook of Family Business American Economic Review, ed. L. Melin, M. Nordqvist, P. Sharma, London: SAGE Publications Ltd., 157-178.

Anderson, R.C., \& Reeb, D.M. (2003). Family funding ownership and firm performance: evidence from S\&P 500. Journal of Finance, 58(3), 1301-1327.

Bammens, Y., Voodeckers, W., \& Van Gils, A. (2011). Board of directors in family businesses: a literature review and research agenda. International Journal of Management Reviews, 13, 134152.

Berrone, P., Cruz, C., \& Gómez-Mejía, L. (2012). Socioemotional Wealth in Family Firms: Theoretical Dimensions, Assessment Approaches, and Agenda for Future Research. Family Business Review, 25(3), 258-279.

Berrone, P., \& Gomez-Mejia, L. (2009). Environmental performance and executive compensation: An integrated agency-institutional perspective. Academy of Management Journal, 52, 103-126.

Bertrand, M., Johnson, S., Samphantharak, K., \& Schoar, A. (2008). Mixing family with business: A study of Thai business groups and the families behind them. Journal of Financial Economics, 88, 466-498.

Carlock, R.S., \& Ward, J.L. (2001). Strategic planning for the family business: parallel planning to unite the family and business. London: Palgrave, MacMillan.

Carney, M., Gedajlovic, E., \& Strike, V.M. (2014). Dead money: Inheritance law and the longevity of family firms. Entrepreneurship Theory and Practice, 38(6), 1261-1283.

Chemla, G., Habib, M.A., \& Ljungqvist, A. (2007). An analysis of shareholder agreements. Journal of the European Economic Association, 5(1), 93-121.

Child, J., \& Rodrigues, S.B. (2003). Corporate governance and new organizational forms: Issues of double and multiple agency. Journal of Management and Governance, 7, 337-360.

Chrisman, J.J., Chua, J.H., \& Sharma, P. (2005). Trends and directions in the development of a strategic management theory of the family firm. Entrepreneurship Theory and Practice, 29, $555-575$.

Chrisman, J.J., Chua, J.H., \& Zahra, S.A. (2003). Creating wealth in family firms through managing resources: comments and extensions. Entrepreneurship Theory and Practice, 27, 359-365.

Chrisman, J.J., Kellermanns, F.W., Chan, K.C., \& Liano, K. (2010). Intellectual foundations of current research in family business: an identification and review of 25 influential articles. Family Business Review, 23(1), 9-26.

Chua, J.H., Chrisman, I.J., Steier, I.P., \& Rau, S.B. (2012). Sources of heterogeneity in family firms: an introduction. Entrepreneurship Theory and Practice, 36, 1103-1113. 
Coles, J. W., McWilliams, V. B., \& Sen, N. (2001). An examination of the relationship of governance mechanisms to performance. Journal of Management, 27, 23-50.

Cruz, C., Becerra, M., \& Gomez-Mejia, L.R. (2010). Perceptions of benevolence and the design of agency contracts: CEO-TMT relationships in family firms. Academy of Management Journal, $53,69-89$.

Cruz, C., Larraza-Kintana, M., Garcés-Galdeano, L., \& Berrone, P. (2014). Are family firms really more responsible? Entrepreneurship Theory and Practice, 38(6), 1295-1316.

Cruz, C., \& Nordqvist, M. (2012). Entrepreneurial orientation in family firms: A generational perspective. Small Business Economics, 38(1), 33-49.

De Kok, J.M.P. de, Uhlaner, L.M., \& Thurik, A.R. (2006). Professional HRM practices in family owned-managed enterprises. Journal of Small Business Management, 44(3), 441-460.

Eddleston, K.A., \& Kellermanns, F.W. (2007). Destructive and productive family relationships: A stewardship theory perspective. Journal of Business Venturing, 22(4), 545-565.

Eddleston, K.A., Kellermanns, F.W., Floyd, S.W., Crittenden, V.L., \& Crittenden, W F. (2013). Planning for growth: Life stage differences in family firms. Entrepreneurship Theory and Practice, 37, 1177-1202.

Fama, E., \& Jensen, M. (1983). Separation of ownership and control. Journal of Law and Economics, $26,301-325$.

Fang, H., Memeli, E., Chrisman, J., \& Welsh, D. (2012). Family firm's professionalization: institutional theory and resource-based view perspectives. Small Business Institute, 8(2), 12-34.

Fiss, P. C. (2008). Institutions and corporate governance. In R. Greenwood, C. Oliver, K. Sahlin, and R. Suddaby. The Sage Handbook of Organizational Institutionalism (390-410). London: SAGE Publications Ltd.

Gallo, M., \& Ward, J. (1991). Family Protocol. Technical Note Research Division, IESE, DGN-448, Barcelona.

Gallo, M.A., \& Tomaselli, S. (2006). Formulating, implementing and maintaining family protocols, in Handbook of Research on Family Business, 298-316. Ed. Edward Elgar.

García-Álvarez, E., \& López-Sintas, J. (2001). A taxonomy of founders based on values: the root of family business heterogeneity. Family Business Review, 14(3), 209-230.

Gedajlovic, E., Lubaktin, M. H., \& Schulze, W. S. (2004). Crossing the threshold from founder management to professional management: a governance perspective. Journal of Management Studies, 41(5), 899-912.

Gersick, K.E., Davis, J.A., Hampton, M.M., \& Lansberg, I. (1997). Generation to generation: Life cycles of the family business. Boston, MA: Harvard Business School Press.

Gersick, K.E., \& Feliu, N. (2014). Governing the family enterprise: practices, performance, and research, in SAGE Handbook of Family Business. Eds. L. Melin, M. Nordqvist and P. Sharma. Thousand Oaks, CA: SAGE, 196-225.

Gomez-Mejia, L.R., Haynes, K.T., Nuñez, M., Jacobson, K.J.L., \& Moyano, H. (2007). Socioemotional wealth and business risk in family controlled firms: Evidence from Spanish olive oil mills. Administrative Science Quarterly, 52, 106-137.

Greenwood, R., Suddaby, R., \& Hinings, C.R. (2002). Theorizing change: The role of professional associations in the transformation of institutionalized fields. Academy of Management Journal, 45(1), 58-80.

Grossman, S., \& Hart, O. (1980). Takeover bids, the free-rider problem, and the theory of the corporation. Rand Journal of Economics, 11, 42-64.

Hoffmann, Ch., Wulf, T., \& Stubner, S. (2014). Understanding the performance consequences of family involvement in the top management team: The role of long-term orientation. International Small Business Journal, 34(3), 345-368.

Holt, D.T., Pearson, A.W., Carr, J.C., \& Barnett, T. (2017). Family firm(s) outcomes model: structuring financial and nonfinancial outcomes across the family and firm. Family Business Review, 30(2), 182-202.

Jaffe, D., \& Lane, S. (2004). Sustaining a family dynasty: Key issues facing complex multigenerational business- and investment-owning families. Family Business Review, 17, 8198. 
Jaskiewicz, P., Combs, J., Shanine, K., \& Kacmar, M. (2017). Introducing the family: A review of family science with implications for management. Academy of Management Annals, 11(1), 309341.

Jaskiewicz, P., \& Dyer, W.G. (2017). Addressing the elephant in the room: disentangling family heterogeneity to advance family business research. Family Business Review, 30(2), 111-118.

Jensen, M. (1986). Agency cost of free cash flow, corporate finance and takeovers. American Economic Review Papers and Proceedings, 76, 323-329.

Johnson, S., La Porta, R., Lopez-de-Silanes, F., \& Shleifer, A. (2000). Tunneling. American Economic Review, 90, 22-7.

Kammerlander, N., Sieger, P., Voordeckers, W., \& Zellweger, T. (2015). Value creation in family firms: A model of fit. Journal of Family Business Strategy, 6, 63-72.

Kidder, L.H., \& Fine, M. (1987). Qualitative and quantitative methods: When stories converge. In New Directions for Evaluation, (35). Ed. Mark, M.M. \& Shotland, R.L., 57-75.

La Porta, R., López de Silanes, F., \& Shleifer, A. (1999). Corporate ownership around the world. Journal of Finance, 54, 471-517.

Leaptrott, J. (2005). An institutional theory view of the family business. Family Business Review, $18(3), 215-228$.

Le Breton-Miller, I., \& Miller, D. (2009). Agency vs. stewardship in public family firms: A social embeddedness reconciliation. Entrepreneurship Theory and Practice, 33, 1169-1191.

Ling, Y., \& Kellermanns, F. (2010). The effects of family firm specific sources of TMT diversity: The moderating role of information exchange frequency. Journal of Management Studies, 47, 322344.

Lubatkin, M.H., Schulze, W.S., Ling, Y., \& Dino, R.N. (2005). The effects of parental altruism on the governance of family-managed firms. Journal of Organizational Behavior, 26(3), 313-330.

Martin, G., Gomez-Mejia, L.R., Berrone, P., \& Makri, M. (2016). Conflict between controlling family owners and minority shareholders: much ado about nothing? Entrepreneurship Theory and Practice, doi:10.1111/etap.12236.

Mazzi, Ch. (2011). Family business and financial performance: Current state of knowledge and future research challenges. Journal of Family Business Strategy, 2, 166-181.

Melin, L., \& Nordqvist, M. (2007). The Reflexive Dynamics of Institutionalization: The Case of the Family Business. Strategic Organization, 5(4), 321-333.

Miller, D., \& Le Breton-Miller, I. (2006). Family governance and firm performance: Agency, stewardship, and capabilities. Family Business Review, 19, 73-87.

Minichilli, A., Corbetta, G., \& MacMillan, I. (2010). Top management teams in family controlled companies: "Familiness", "Faultiness" and the impact on Financial performance. Journal of Managerial Studies, 47, 205-222.

Montemerlo, D., \& Ward, J.L. (2005). The Family Constitution, Agreements to perpetuate your family and your business. (1st. ed.). Marietta, GA: Family Enterprise Publishers.

Morck, R., Wolfenzon, D., \& Bernard, Y. (2005). Corporate governance, economic entrenchment, and growth. Journal of Economic Literature, 43(3), 655-720.

Naldi, L., Chirico, F., Kellermanns, F.W., \& Campopiano, G. (2015). All in the family? an exploratory study of family member advisors and firm performance. Family Business Review, 28(3), 227242.

Nordqvist, M., \& Melin, L. (2002). The dynamics of family firms: an institutional perspective on corporate governance and strategic change. In D. E. Fletcher, Understanding the Small Family Business, 94-110. New York: Routledge.

Nordqvist, M., Sharma, P., \& Chirico, F. (2014). Family firm heterogeneity and governance: A configuration approach. Journal of Small Business Management, 52(2), 192-209.

O'Boyle, E.H., Pollack, J.M., \& Rutherford, M.W. (2012). Exploring the relation between family involvement and firms' financial performance: A meta-analysis of main and moderator effects. Journal of Business Venturing, 27, 1-18.

Parada, M. J., Nordqvist, M., \& Gimeno, A. (2010). Institutionalizing the family business: The role of professional associations in fostering the change of values. Family Business Review, 23(4), 355372.

Penrose, E.T. (1959). The Theory of the Growth of the Firm. New York: John Wiley. 
Pérez-González, F. (2006). Inherited control and firm performance. American Economic Review, 96(5), 1559-1588.

Schulze, W.S., Lubatkin, M.H., Dino, R.N., \& Buchholtz, A.K. (2001). Agency relationships in family firms: Theory and evidence. Organization Science, 12(2), 99-116.

Sciascia, S., \& Mazzola, P. (2008). Family involvement in ownership and management: exploring nonlinear effects on performance. Family Business Review, 21(4), 331-344.

Shleifer, A., \& Vishny, R. (1997). A survey of corporate governance. The Journal of Finance, 52(2), 737-783.

Strike V. M. (2012). Advising the family firm: Reviewing the past to build the future. Family Business Review, 25, 156-177.

Tagiuri, R, \& Davis, J. (1996). Bivalent attributes of the family firm. Family Business Review, 9(2), 199-208.

Tapies, J., \& Ceja, L. (2011). Family Protocol: Better to agree and put it in writing. IESE insight.

Van den Berghe, L.A.A., \& Carchon, S. (2003). Agency relations within the family business system: an exploratory approach. Corporate Governance: An International Review, 11(3), 171-179.

Vardaman, J.M., \& Gondo, M.B. (2014). Socioemotional wealth conflict in family firms. Entrepreneurship Theory and Practice, 38(6), 1317-1322.

Villalonga, B., \& Amit, R. (2006). How do family ownership, control and management affect firm value? Journal of Financial Economics, 80, 385-417.

Villalonga, B., Amit, R., Trujillo, M.A., \& Guzman, A. (2015). Governance of family firms. Annual Review of Financial Economics, 7, 635-654.

Westhead, P., \& Howorth, C. (2007). 'Types' of private family firm: An exploratory conceptual and empirical analysis. Entrepreneurship \& Regional Development, 19, 405-431.

Zellweger, T., \& Kammerlander, N. (2015). Family, Wealth, and Governance: An Agency Account. Entrepreneurship Theory and Practice, 39(6), 1281-1303.

\section{Author Biographies}

Rocio Arteaga is a $\mathrm{PhD}$ candidate at the University of Oviedo in the Area of Economy. Her research interests include family firms, corporate governance, and strategic entrepreneurship.

Susana Menéndez-Requejo, PhD, is Full Professor in Finance at the University of Oviedo (Spain). She was the Director of the Family Business Chair at the same University and holds a Certificate in Family Business Advising from the Family Firm Institute. Her research interests are in the areas of Corporate Finance (capital structure, corporate governance, mergers and acquisitions) and Family Firms. 